\title{
COMPARATIVE ANALYSIS OF DIFFERENT STRATEGIES FOR THE CONTROL OF CLASSICAL SWINE FEVER IN THE REPUBLIC OF SERBIA USING MONTE CARLO SIMULATION
}

\author{
Slavoljub Stanojević ${ }^{1}$, Miroslav Valćić ${ }^{2}$, Sonja Radojičić ${ }^{2}$, \\ Slobodan Stanojević́ ${ }^{3}$, Stevan Avramov ${ }^{4}$, Sava Lazić ${ }^{5}$, Dušan Mišić ${ }^{2}$ \\ ${ }^{1}$ Ministry of Agriculture and Environment Protection - \\ Directorate of National Reference Laboratory \\ ${ }^{2}$ Faculty of Veterinary Medicine -University of Belgrade \\ ${ }^{3}$ Scientific Veterinary Institute of Serbia, Beograd \\ ${ }^{4}$ Institute for Biological Research "Siniša Stanković" Belgrade \\ ${ }^{5}$ Scientific Veterinary Institute Novi Sad, Novi Sad
}

\section{Abstract}

Several different strategies for control and eradication of Classical Swine Fever (CSF) were compared using a Monte Carlo method-based simulation model. The control strategy analyzed in this paper, in addition to other CSF control measures, includes application of biosecurity measures on pig farms and rural backyard holdings. Elements of the control strategy are based on applicable regulations and include the simulation of detection of the disease, setting up the protected and surveillance zones, standstill of pig movements and restricted movement of animals, vehicles, equipment, and people with strong control measures in protection and surveillance zones, euthanasia of susceptible pigs, protective vaccination of pigs, compensation etc. During the simulation, different output parameters were compared such as: duration of epizootic of a disease, number of affected holdings and animals, direct costs such as those for dead or culled animals, costs of surveillance, disposal of infectious materials, cleaning and disinfection. Depopulation of affected animals with early diagnostics and vaccination in protection and surveillance zone proved to be the most effective measures to stop spreading and eradication of the disease. However, during the simulation, systematic implementation of biosecurity measures in all pig production clusters demonstrated to be appropriate strategy for sustainable

\footnotetext{
${ }^{1}$ Corresponding author: slavoljub.stanojevic@minpolj.gov.rs
} 
control of CSF and setting up a stable epizootiological situation.

Key words: classical swine fever, Monte Carlo, biosecurity measures, control strategy

\title{
KOMPARATIVNA ANALIZA RAZLIČITIH STRATEGIJA ZA KONTROLU KLASIČNE SVINJSKE KUGE UPOTREBOM MONTE CARLO SIMULACIJE
}

\author{
Slavoljub Stanojević ${ }^{1}$, Miroslav Valćić ${ }^{2}$, Sonja Radojičić \\ Slobodan Stanojević ${ }^{3}$, Stevan Avramov ${ }^{4}$, Sava Lazić ${ }^{5}$, Dušan Mišić ${ }^{2}$ \\ ${ }^{1}$ Ministarstvo poljoprivrede izaštite životne sredine - Direkcija za nacionalne \\ referentne laboratorije \\ ${ }^{2}$ Fakultet veterinarske medicine, Univerziteta u Beogradu \\ ${ }^{3}$ Naučni institut za veterinarstvo Srbije, Beograd \\ ${ }^{4}$ Institut za biološka istraživanja "Siniša Stanković”, Beograd \\ ${ }^{5}$ Naučni institut za veterinarstvo "Novi Sad", Novi Sad
}

\section{Kratak sadržaj}

Nekoliko različitih strategija za kontrolu i iskorenjivanje klasične kuge svinja je upoređivano primenom modela simulacije zasnovanog na Monte Karlo metodi. Kontrolne strategije koje su obrađivane u ovom radu, pored opštih i posebnih mera suzbijanja KKS, uključuju i različite nivoe primenjenih biosigurnosnih mera na komercijalnim, porodičnim farmama i seoskim gazdinstvima na kojima se ga je svinje. Mere neškodljivog uništavanja obolelih životinja i životinja koje su bile u kontaktu sa obolelim životinjama, uspostavljanje zaštitnih zona pod nadzorom, kontrola i zaustavljanje prometa životinja i mehaničkih vektora (vozila i ljudi) unutar zona, rano otkrivanje bolesti i mera vakcinacije su bile uključene u simulaciju. Izlazni parametri kao što su: vreme trajanja epizootije, broj zaraženih gazdinstava i životinja, broj uništenih životinja, troškovi nadzora i direktne štete nastale zbog pojavljivanja bolesti s upoređivani tokom simulacije. Vakcinacija, neškodljivo uklanjanje obolelih životinja i rana dijagnostika su se pokazale kao najefektivnije mere zaustavljanja širenja i iskorenjivanja bolesti. Međutim, kao mera dugoročne strategije kontrole KKS i uspostavljanja stabilne epizootiološke situacije, tokom simulacije pokazala se mera planskog i sistematskog podizanja biosigurnosnih mera u svim klasterima proizvodnje 
svinja (komercijalne farme, porodične farme tipa A, porodične farme tipa B i seoska gazdinstva).

Ključne reči: klasična kuga svinja, Monte Karlo, biosigurnosne mere, kontrolna strategija

\section{INTRODUCTION}

Classical swine fever (CSF) is highly contagious disease of viral etiology affecting domestic and wild pigs. From economic aspect, CSF is the most severe threat to national pig industry in all countries. The disease is spread worldwide and is reported at all continents. Models and simulation of CSF epizootics enables assessment of disease dynamics as well as economic effects of implemented control measures. The objective of this article is to analyse potential control strategies for eradication of CSF in the Republic of Serbia based predominantly on improvement of biosecurity measures on a typical rural holdings and gradual upgrading of rural holdings to higher farm categories.

\section{MATERIAL AND METHODS}

\section{Description of the simulation model}

The simulation has been conducted in the territory of the municipalities of Sremska Mitrovica and Šid. The area is characterized by high density of pigs as well as substantially heterogeneous pig-breeding technology, production habits and policies as well as production scale. The simulation encompassed all pig-breeding holdings including commercial farms, family farms type A, family farms type B and backyard holdings. The data on the number of pigs, production categories, and geographical locations were collected during the field investigation or obtained from the Central Database of Ministry of the Agriculture. Data processing was performed using ARC GIS 10.0. software package (Gatrell, 2004; Stanojevic, 2014). In cases where data about geographical location of rural holdings were not accessible, these were obtained from the Central Database of Ministry of Agriculture and the geographic coordinates were determined in ARC GIS 10.0, by randomly selecting (Gatrell, 2004). The simulation was performed applying the North American Animal Disease Spread Model based on the Monte Carlo method. NAADSM is a computer program based on the Monte Carlo method and is developed for the simulation of contagious animal diseases. The software was developed by a team of experts of the Center for Epidemiology and Animal Health US Department of Agriculture from Fort Collins, Colorado (Jalvingh et al., 1999; Harvey et al., 2007; Reeves et al., 2012). 
The basic idea underlying the Monte Carlo method is the approximation of the expected value $\mathrm{E}(X)$ by the arithmetic mean of the results of a large number of independent tests all with the same distribution as $X$. The stochastic simulations use random variables and are based on the law of random numbers (Jalvingh et al., 1999).The model simulates daily disease transmission between farms and rural holdings for pig production. The simulation includes both direct and indirect contacts. The events such as "contact between the various epizootical units - adequate contact" and "contact between the various units that caused the transmission of diseases - effective contact" are generated stochastically. The variability of the obtained results after 1,000 replications provide the information about the potential pattern of disease spreading (Gatrell, 2004; Engel et al., 2005; Harvey et al., 2007).At the beginning of the simulation, all backyard holdings and farms are considered "susceptible", except in cases where a number of pigs are vaccinated. Once acquiring the status "infected", a holding/farm has to pass through all other statuses predefined in the model. Table 1. describes the definition of the disease transition states.

Table 1. Definition of statuses through which animals pass in the model

\begin{tabular}{|l|l|}
\hline Status & Definition of status \\
\hline Susceptible & $\begin{array}{l}\text { All animals in the herd not infected and can be in- } \\
\text { fected in case of contact with a diseased animal. }\end{array}$ \\
\hline Latent & $\begin{array}{l}\text { Period between exposure and infection. Some animals } \\
\text { in the herd are infected, but still do not shed the virus. }\end{array}$ \\
\hline $\begin{array}{l}\text { Subclinical } \\
\text { infection }\end{array}$ & $\begin{array}{l}\text { Some animals in the herd are infected and } \\
\text { shed the virus. No clinical symptoms. }\end{array}$ \\
\hline $\begin{array}{l}\text { Clinical in- } \\
\text { fection }\end{array}$ & $\begin{array}{l}\text { Some animals in the herd are infected, shed the vi- } \\
\text { rus, and show a clinical image of the disease. }\end{array}$ \\
\hline Vaccinated & $\begin{array}{l}\text { Animals in the herd are vaccina- } \\
\text { ted and are not susceptible to CSF. }\end{array}$ \\
\hline $\begin{array}{l}\text { Dead from } \\
\text { disease }\end{array}$ & Animals died due CSF \\
\hline Culled & $\begin{array}{l}\text { All animals in the herd are culled during im- } \\
\text { plementation of CSF eradication measures. }\end{array}$ \\
\hline
\end{tabular}

After a short period of latency, all infected pigs disseminate the virus 
among susceptible population. However, there are certain differences in probability of an outbreak of the disease after adequate contact. Such differences are determined by intensity of direct and indirect contact between animals, the type of the holding and farming system itself as well as the level of implemented biosecurity measures. Some potential scenarios entail that certain number of pigs is vaccinated, thus possessing artificially induced immunity, which makes them non-susceptible. Defining parameters for disease spread sets down the modelling of control measures, laid down by relevant regulations. Upon completing the simulation, the following data are analysed: total number of infected farms and holdings, total number of diseased and culled animals, number of farms and holding where euthanasia was performed, duration of the outbreak, financial data such as costs of euthanasia, disinfection and cleaning, expenses of safe disposal of carcasses, costs of laboratory examination etc. Depending on the scenario, several hypothetic situations were simulated including preventive vaccination of animals and no-vaccination scenario. The initial scenario describes actual status of CSF control in Serbia. Other scenarios simulated spread of the disease in conditions with no vaccination or emergency vaccination aimed at preventing virus transmission outside of infested area (Table 2).

Table 2. Scenario set up

\begin{tabular}{|c|c|c|c|c|c|c|c|}
\hline No. & $\begin{array}{l}\text { Pre- } \\
\text { ventive } \\
\text { vacci- } \\
\text { nation } \\
\text { policy }\end{array}$ & $\begin{array}{l}\text { Herd } \\
\text { immu- } \\
\text { nity }\end{array}$ & $\begin{array}{l}\text { Protective } \\
\text { vaccinati- } \\
\text { on (radius) }\end{array}$ & $\begin{array}{l}\text { Depopulation: } \\
\mathrm{r}=500 \mathrm{~m} \\
\text { around } \\
\text { infected farm }\end{array}$ & $\begin{array}{l}\text { Depopu- } \\
\text { lation: } \\
\mathrm{r}=100 \mathrm{~m} \\
\text { around in- } \\
\text { fected farm }\end{array}$ & $\begin{array}{l}\text { Depopulati- } \\
\text { on: } \mathrm{r}=50 \mathrm{~m} \\
\text { around } \\
\text { infected } \\
\text { farm }\end{array}$ & $\begin{array}{l}\text { Biose- } \\
\text { curity } \\
\text { mea- } \\
\text { sures }\end{array}$ \\
\hline 1. & yes & $49 \%$ & - & $\begin{array}{c}\mathrm{CF}, \mathrm{A}, \mathrm{B}, \\
\mathrm{RH} 1, \mathrm{SG} 2\end{array}$ & - & - & - \\
\hline 2. & yes & $49 \%$ & - & $\mathrm{CF}$ & A & $\begin{array}{c}\mathrm{B}, \mathrm{RH} 1, \\
\text { RH2 }\end{array}$ & - \\
\hline 3. & yes & $49 \%$ & - & $\mathrm{CF}$ & - & $\begin{array}{c}\mathrm{A}, \mathrm{B}, \mathrm{RH} 1, \\
\mathrm{RH} 2\end{array}$ & - \\
\hline 4. & yes & $49 \%$ & - & - & $\mathrm{CF}$ & $\begin{array}{c}\mathrm{A}, \mathrm{B}, \mathrm{RH} 1, \\
\mathrm{RH} 2\end{array}$ & - \\
\hline 5. & no & $0 \%$ & ne & $\begin{array}{l}\text { CF, A, B, } \\
\text { RH1, SG2 }\end{array}$ & - & - & - \\
\hline
\end{tabular}




\begin{tabular}{|c|c|c|c|c|c|c|c|}
\hline 6. & no & $0 \%$ & $10 \mathrm{~km}$ & CF & A & $\begin{array}{c}\text { B, RH1, } \\
\text { RH2 }\end{array}$ & - \\
\hline 7. & no & $0 \%$ & $3 \mathrm{~km}$ & $\mathrm{CF}$ & A & $\begin{array}{c}\text { B, RH1, } \\
\text { RH2 }\end{array}$ & - \\
\hline 8. & no & $0 \%$ & $10 \mathrm{~km}$ & $\mathrm{CF}$ & - & $\begin{array}{c}\mathrm{A}, \mathrm{B}, \mathrm{RH} 1, \\
\mathrm{RH} 2\end{array}$ & \\
\hline 9. & no & $0 \%$ & $3 \mathrm{~km}$ & CF & - & $\begin{array}{c}\mathrm{A}, \mathrm{B}, \mathrm{RH} 1, \\
\mathrm{RH} 2\end{array}$ & \\
\hline 10. & no & $0 \%$ & $10 \mathrm{~km}$ & - & CF, A & $\begin{array}{c}\text { B, RH 1, } \\
\text { RH } 2\end{array}$ & - \\
\hline 11. & no & $0 \%$ & $3 \mathrm{~km}$ & - & $\mathrm{CF}, \mathrm{A}$ & $\begin{array}{c}\text { B, RH 1, } \\
\text { RH } 2\end{array}$ & - \\
\hline 12. & no & $0 \%$ & $3 \mathrm{~km}$ & - & CF, A & $\begin{array}{c}\text { B, RH 1, } \\
\text { RH } 2\end{array}$ & $\begin{array}{c}\text { no } \\
\text { natural } \\
\text { mating } \\
\text { (NNM) }\end{array}$ \\
\hline 13. & no & $0 \%$ & $3 \mathrm{~km}$ & - & $\mathrm{CF}, \mathrm{A}$ & $\begin{array}{c}\mathrm{B}, \mathrm{RH} \\
\mathrm{RH} 2\end{array}$ & $\begin{array}{c}\mathrm{NNM} \\
\& 25 \% \\
\text { indirect } \\
\text { con- } \\
\text { tacts }\end{array}$ \\
\hline 14. & no & $0 \%$ & $3 \mathrm{~km}$ & - & CF, A & $\begin{array}{l}\text { B, RH } 1, \\
\text { RH } 2\end{array}$ & $\begin{array}{l}\text { NNM } \\
\& 50 \% \\
\text { indi- } \\
\text { rect } \\
\text { con- } \\
\text { tacts }\end{array}$ \\
\hline
\end{tabular}

CF-commercial farm; A- family farm type A; B-family farm type B; RH1rural holding category $1 ; \mathrm{RH} 2$ - rural holding category 2

Disease parameters

The diseases characteristics and input parameters, used for analysis with NAADSM are based on data from literature and results of retrospective analyses of CSF cases in the Republic of Serbia in 2005, 2006 and 2007 (Table 3) (Backer et al., 2011). 
Table 3. Disease transmission parameters

\begin{tabular}{|c|c|c|c|}
\hline Parameters & $\begin{array}{l}\text { Probability } \\
\text { distribution }\end{array}$ & \multicolumn{2}{|c|}{$\begin{array}{l}\text { The mean value / stan- } \\
\text { dard deviation in days }\end{array}$} \\
\hline $\begin{array}{l}\text { The latent period } \\
\text { (Laddomada, 2000) }\end{array}$ & $\begin{array}{l}\text { Poisson dis- } \\
\text { tribution }\end{array}$ & \multicolumn{2}{|l|}{$7(1) ; 8(1)$} \\
\hline $\begin{array}{l}\text { Subclinical period } \\
\text { (Martinez-Lo- } \\
\text { pez et al., 2011) }\end{array}$ & $\begin{array}{l}\text { Poisson dis- } \\
\text { tribution }\end{array}$ & \multicolumn{2}{|l|}{21} \\
\hline $\begin{array}{l}\text { Infectious period } \\
\text { (Baker et al., 2011) }\end{array}$ & $\begin{array}{l}\text { Gamma dis- } \\
\text { tribution }\end{array}$ & \multicolumn{2}{|c|}{ Alfa: 13.5 , beta: 1} \\
\hline $\begin{array}{l}\text { Immune period after } \\
\text { vaccination } \\
\text { (Qui et al., 2006) }\end{array}$ & $\begin{array}{l}\text { The normal } \\
\text { Gaussian } \\
\text { distribution }\end{array}$ & \multicolumn{2}{|l|}{$300 / 60$} \\
\hline $\begin{array}{l}\text { The number of di- } \\
\text { rect contacts between } \\
\text { animals daily- direct } \\
\text { sales to owners * }\end{array}$ & $\begin{array}{l}\text { Poisson dis- } \\
\text { tribution }\end{array}$ & $\begin{array}{l}\text { Type of farm } \\
\text { Industrial farms } \\
\text { Type A } \\
\text { Type B } \\
\text { Back yard farm }\end{array}$ & $\begin{array}{l}\text { Intensity } \\
0.07 \\
0.009 \\
0.0074 \\
0.0036\end{array}$ \\
\hline $\begin{array}{l}\text { Number of contacts } \\
\text { direct natural mating } \\
\text { (mating animals) }\end{array}$ & $\begin{array}{l}\text { Poisson dis- } \\
\text { tribution }\end{array}$ & $\begin{array}{l}\text { Type of farm } \\
\text { Type B } \\
\text { Rural farm }\end{array}$ & $\begin{array}{l}\text { Intensity } \\
0.016 \\
0.0057\end{array}$ \\
\hline $\begin{array}{l}\text { The probability of tran- } \\
\text { smission of the virus } \\
\text { through direct contact } \\
\text { if the farm / farm sour- } \\
\text { ce of infection (Kar- } \\
\text { sten et al., 2005a) }\end{array}$ & $\begin{array}{l}\text { Bernoulli } \\
\text { distribution }\end{array}$ & $\begin{array}{l}\text { Type of farm } \\
\text { Industrial farms } \\
\text { Type A } \\
\text { Type B } \\
\text { Rural farm }\end{array}$ & $\begin{array}{l}\text { Probability } \\
0.7 \\
0.7 \\
0.8 \\
0.8\end{array}$ \\
\hline $\begin{array}{l}\text { Number of indirect } \\
\text { contacts per day* }\end{array}$ & $\begin{array}{l}\text { Poisson dis- } \\
\text { tribution }\end{array}$ & $\begin{array}{l}\text { Type of farm } \\
\text { Industrial farms } \\
\text { Type A } \\
\text { Type B } \\
\text { Rural farm } \\
\end{array}$ & $\begin{array}{l}\text { Intensity } \\
0.1428 \\
0.1428 \\
0.0330 \\
0.2850 \\
\end{array}$ \\
\hline $\begin{array}{l}\text { Local spread of the virus } \\
\text { (Karsten et al., 2005a) }\end{array}$ & $\begin{array}{l}\text { Bernoulli } \\
\text { distribution }\end{array}$ & $\begin{array}{l}\text { Distance from the } \\
\text { farm } \\
150 \mathrm{~m} \\
150-250 \mathrm{~m} \\
250-500 \mathrm{~m} \\
500-1000 \mathrm{~m}\end{array}$ & $\begin{array}{l}\text { Mean value } \\
0.020 \\
0.010 \\
0.004 \\
0.002\end{array}$ \\
\hline
\end{tabular}




\begin{tabular}{|c|c|c|c|}
\hline Parameters & $\begin{array}{l}\text { Probability } \\
\text { distribution }\end{array}$ & $\begin{array}{l}\text { The mean value / st } \\
\text { dard deviation in d }\end{array}$ & \\
\hline $\begin{array}{l}\text { The probability of detec- } \\
\text { ting the first appearance of } \\
\text { clinical symptoms of CSF } \\
\text { from the moment when } \\
\text { the farm became infec- } \\
\text { tious (Engel et al., 2005) }\end{array}$ & Fixed value & \begin{tabular}{|c|} 
Number of days \\
8 \\
10 \\
20 \\
25 \\
37 \\
47 \\
50 \\
\end{tabular} & $\begin{array}{c}\text { Probability } \\
0 \% \\
3 \% \\
7 \% \\
10 \% \\
50 \% \\
90 \% \\
100 \%\end{array}$ \\
\hline $\begin{array}{l}\text { The probability of detec- } \\
\text { ting cases of death due } \\
\text { to infection by the CSFV } \\
\text { from the time of occu- } \\
\text { rrence of the first cases of } \\
\text { death (placing suspected } \\
\text { on the basis of the fin- } \\
\text { dings pathoanatomic) } \\
\text { (Klinkenberg et al., 2005) }\end{array}$ & Fixed value & \begin{tabular}{|c|} 
Number of days \\
1 \\
2 \\
3 \\
4 \\
5 \\
6 \\
7 \\
8 \\
\end{tabular} & $\begin{array}{l}\text { Probability } \\
20 \% \\
30 \% \\
40 \% \\
50 \% \\
60 \% \\
70 \% \\
80 \% \\
100 \% \\
\end{array}$ \\
\hline $\begin{array}{l}\text { The probability of } \\
\text { successful tracking } \\
\text { of shipments of ani- } \\
\text { mals that have left an } \\
\text { infected farm }\left(^{* *}\right)\end{array}$ & $\begin{array}{l}\text { Bernoulli } \\
\text { distribution }\end{array}$ & $\begin{array}{l}\text { Type of farm } \\
\text { Commercial Farm } \\
\text { Family farm type A } \\
\text { Family farm type B } \\
\text { Rural farm }\end{array}$ & $\begin{array}{c}\text { Mean value } \\
0.80 \\
0.80 \\
0.80 \\
0.40 \\
\end{array}$ \\
\hline $\begin{array}{l}\text { The probability of succe- } \\
\text { ssful detection and moni- } \\
\text { toring of indirect contact } \\
\text { with infected farm (Mar- } \\
\text { tinez-Lopez et al., 2011) }\end{array}$ & $\begin{array}{l}\text { Bernoulli } \\
\text { distribution }\end{array}$ & $\begin{array}{l}\text { Type of farm } \\
\text { Commercial Farm } \\
\text { Family farm type A } \\
\text { Rural farm }\end{array}$ & $\begin{array}{c}\text { Mean value } \\
0.95 \\
0.90 \\
0.20\end{array}$ \\
\hline $\begin{array}{l}\text { Sensitivity and specifi- } \\
\text { city of diagnostic tests }\end{array}$ & Fixed value & $\begin{array}{l}\text { Sensitivity } \\
\text { Specificity }\end{array}$ & $\begin{array}{l}99 \% \\
99 \%\end{array}$ \\
\hline
\end{tabular}

* Data collected in the field

${ }^{* *}$ Data based on CSF epidemic in Serbia in 2010 
Arhiv veterinarske medicine, Vol. 9, No. 1, 43 - 59, 2016

Stanojević S. ... et al.: Comparative analysis of different...

Figure 1. Latent period

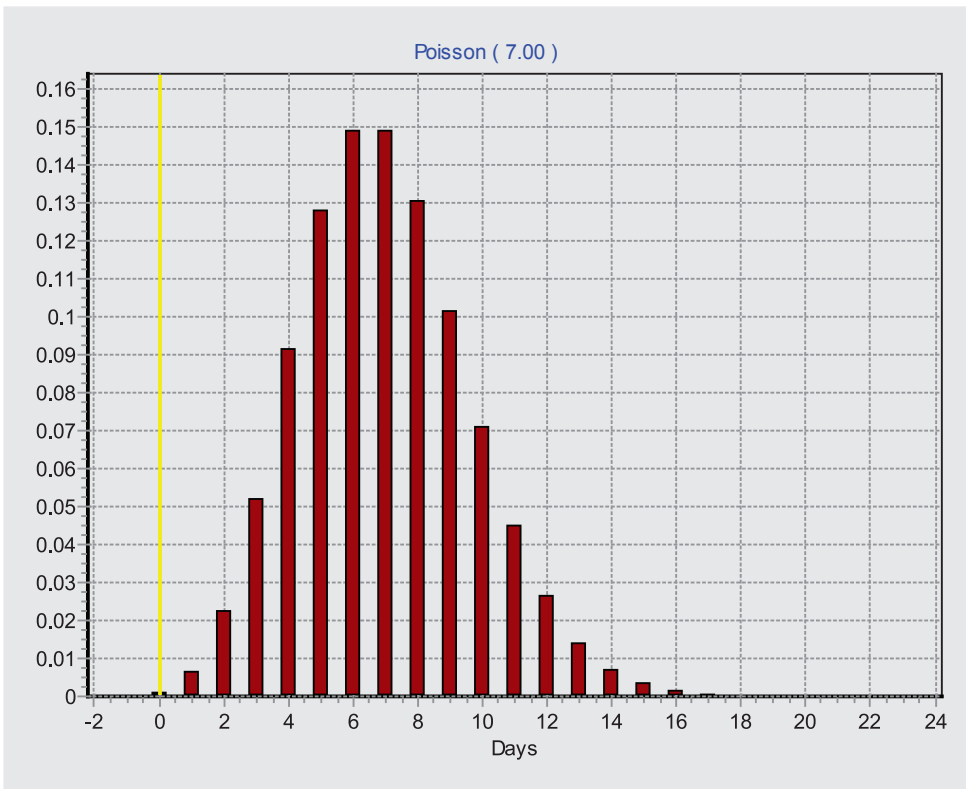

Figure 1. Clinical infectious period

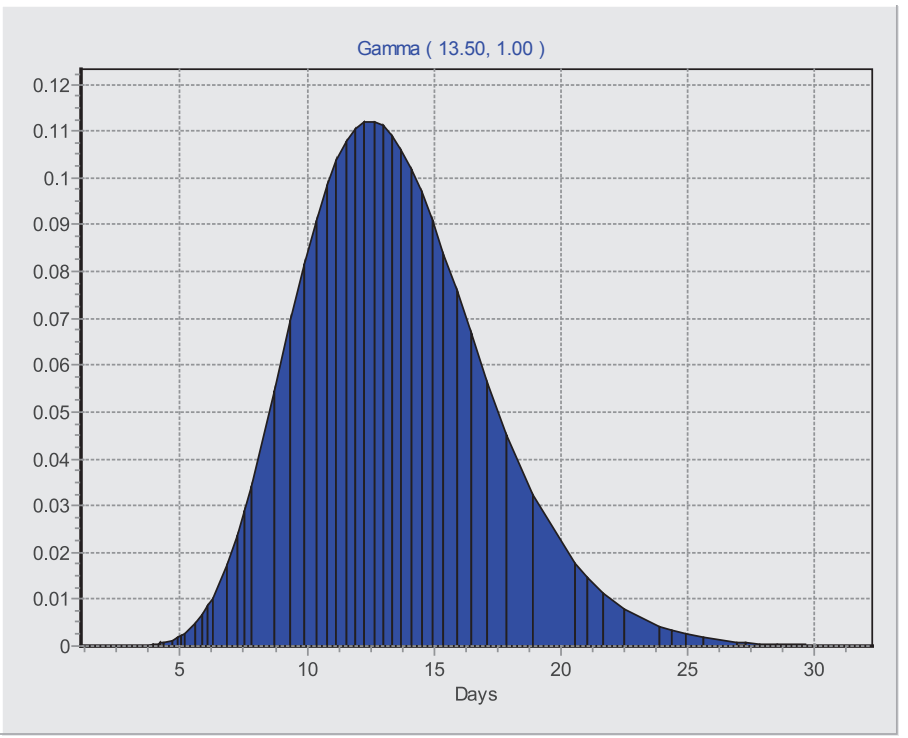


Figure 3. The probability of detection of first cases or observing clinical signs of CSF on industrial farm, type A, B and backyard farm. The detection probability was modeled as based on the results from Klinkenberg et al. (2005) and Engel et al. (2005) and available data from epidemics of CSF in Serbia between 2005 and 2010.

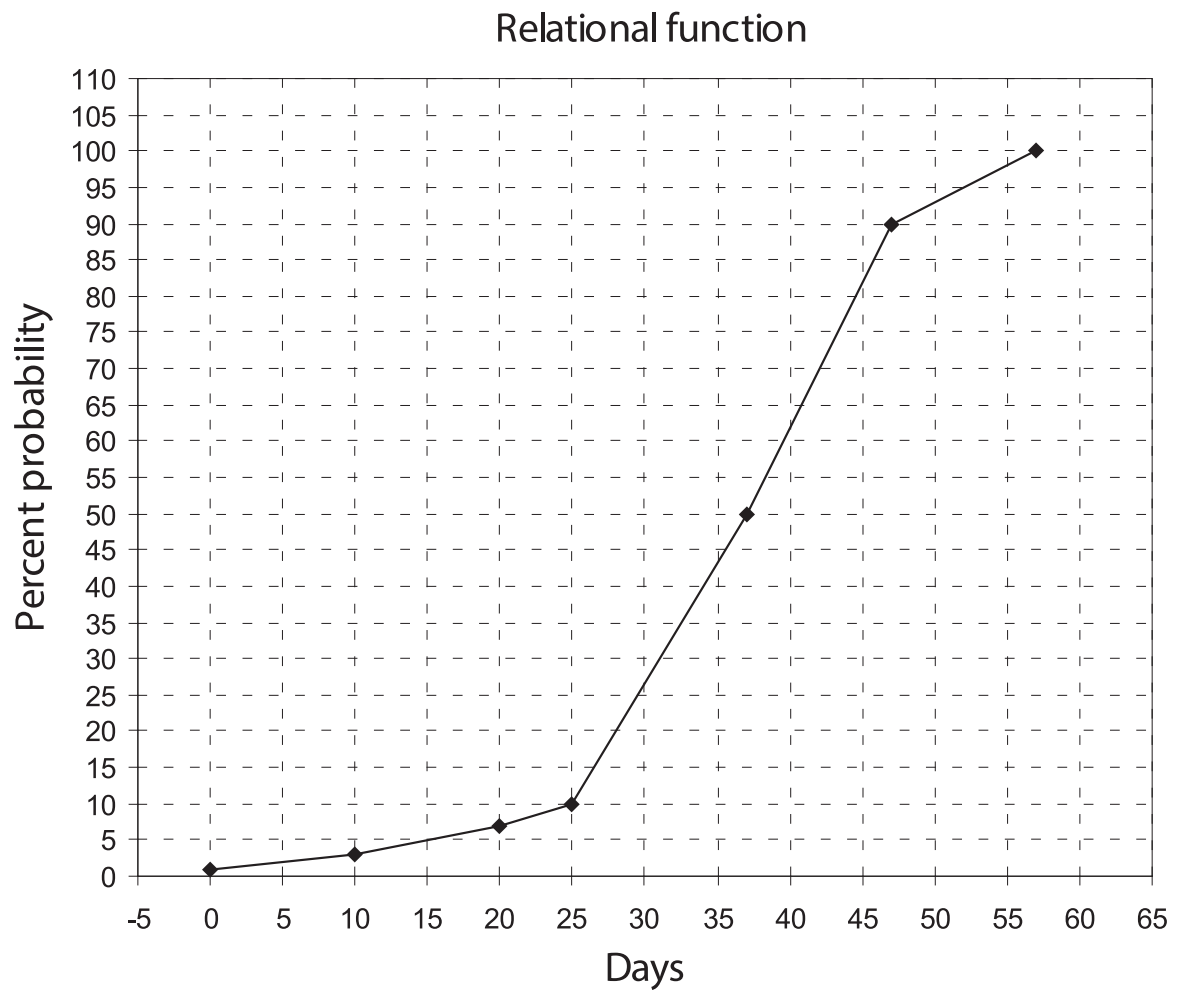

\section{RESULTS}

Simulation of the scenario No.1 entailed analysis of the effects of implementation of currently relevant measures for CSF control in case of disease outbreak, taking into consideration factors such as actual production conditions and capacities of field veterinary service. Scenarios 2-4 dealt with potential modifications of current control strategies and the assessment of their effects when applied in conditions of CSF control using preventive vaccination policy. In scenarios No. 5-14, hypothetical situations of no-vaccination CSF control were tested. The testing included also the hypothesis on CSF control using protective vaccination as well as the improvement of biosecurity meas- 
ures on rural holdings and family farms type B such as restriction of natural mating and intensity of indirect contacts. Fourteen different hypothetical scenarios have been analysed (Table 2).

The analysis of obtained results revealed that CSF control using preventive vaccination strategy results in less direct economic losses, less number of diseased and culled animals as well as significantly shorter duration of the epizootic. The simulation indicated that the area for preventive euthanasia of pigs should be set to a radius of $\max 50 \mathrm{~m}$ around extensive rural holdings and family farms type $A$ and $B$, and $500 \mathrm{~m}$ around commercial pig farms. The simulation also revealed no statistically significant differences regarding duration of epidemics, number of infected holding or animals even if the depopulation radius was limited to $100 \mathrm{~m}$ around the infected commercial farm.

The most severe losses were observed in a scenario that was identical with the current field conditions, yet presuming cessation of vaccination program and absence of protective vaccination in case of CSF outbreak. In scenarios No. 12,13 and 14 characterized by absence of preventive vaccination but with restricted natural mating and improved biosecurity measures on rural holdings and family farms type $B$, the results revealed statistically significant decrease in number of diseased animals as well as lower economic damage.

In conditions of termination of vaccination, the scenario No. 9 proved most appropriate, that is, the following measures are most effective: depopulation radiuses set to $500 \mathrm{~m}$ and $50 \mathrm{~m}$ around commercial farms and rural holdings/family farms type A and B, respectively; implementation of protective vaccination policy and other measures laid down in relevant legislation. In all simulation models, there were no statistically significant differences between the effects of protective vaccination applied in the radius of $10 \mathrm{~km}$ or $3 \mathrm{~km}$ around the commercial farms.

Table 4 depicts the results obtained in simulation models for 14 different scenarios. In scenarios No.1-4, potential modification of current CSF control strategy relying on preventive vaccination are analysed. The results obtained in simulation scenario No. 5 indicated that veterinary service is unable to control CSF without protective vaccination. As obvious from Table 4, implementation of controlled natural mating in case of CSF outbreak results in statistically significant decrease in number of diseased animals as compared with scenarios lacking this measure (scenario No. 12 in Table 4).

Furthermore, if controlled natural mating in case of an outbreak of CSF would be associated with a decrease in intensity of indirect contacts for $25 \%$ and $50 \%$, the number of diseased animals would be even more decreased (scenarios No. 13-14, Table 4). 
Graph 1. Comparative graph of total economic damage expressed in EUR

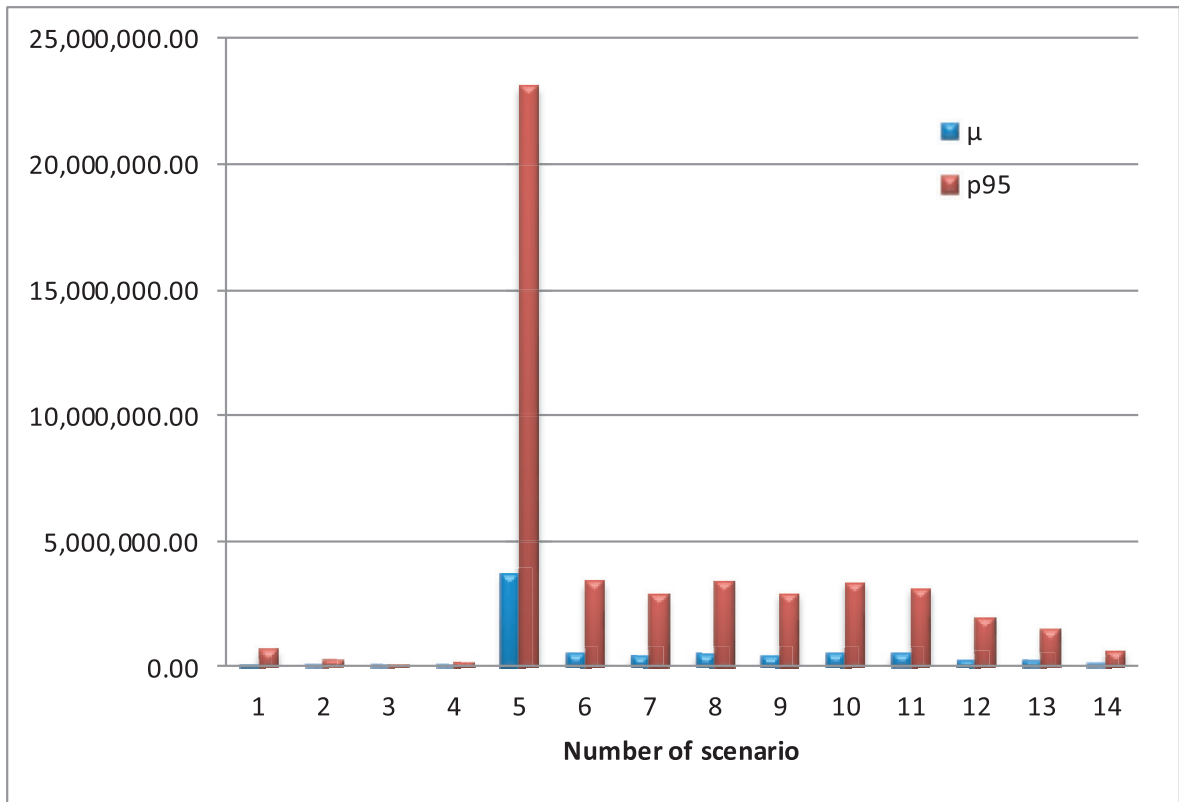

\section{Legend:}

- CFS control applying preventive vaccination (scenarios 1-4);

- No-vaccination CFS control (scenario5);

- CFS control applying protective vaccination as the alternative to mass pig (scenarios 6-11);

- CFS control applying protective vaccination and improvement of biosecurity measures at rural holding and family farms type B (scenarios 12-14). 


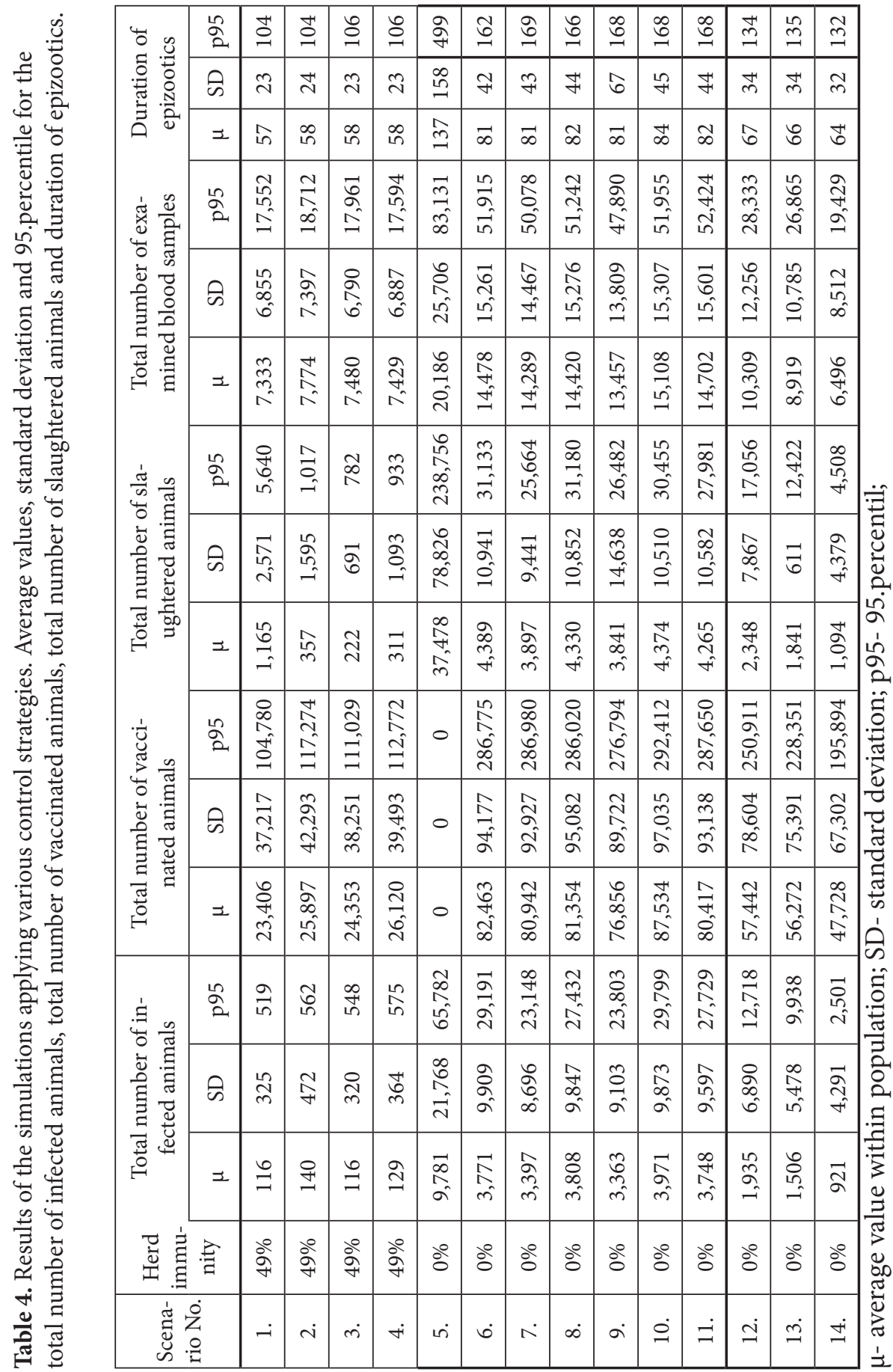




\section{DISCUSSION}

Simulation and mathematic modelling enable the pre-estimation of optimal control strategies, quantification of potential epizootic outcomes, adjustment of relevant control plans, assessment of veterinary service and necessary resources (Jalvingh et al., 1999; Karsten et al., 2005a). This research offered a review of potential outcomes of CSF outbreak in a limited area characterized by high pig density and highly heterogeneous pig production system. Potential dynamics of CSF epizootic as well as the level of consequent damage were described relating to different approaches to disease control and eradication. The simulation revealed that rural holdings are highly susceptible to CSF; however, in such holdings, the potential for virus spread over large distance is lower, which corresponds with simulation results reported in Bulgaria (Backer et al., 2011). Spread of the disease over large distances is mainly associated with family farms type A and B and commercial farms. Rural holdings producing pigs for their own needs are not considered to be of high potential risk for disease transmission. The simulation model also suggested that, when speaking of rural holdings, local transmission is the most common route of infection with $\mathrm{CSF}$ virus. As regards the farms type $\mathrm{B}$, most common infection routes include both local spreading and indirect contacts. The obtained results correspond with the results of the study analysing the potential of local spread of CSF virus conducted in Holland during a CSF epidemics in 1997-1998 (Karsten et al., 2005b; Klinkenberg et al., 2005). The simulation emphasized the role of uncontrolled natural mating in disease spreading at settlement level. Occurrence of CSF on family farms type A is mostly associated with the purchase of animals for fattening from producers from family farms type B and rural holdings. When speaking of commercial farms, two potential risk factors are most commonly associated with CSF outbreaks - introduction of infected animals into the herd and contacts with rural holdings through the personnel employed at the farm, who have their own pigs at home. Safe elimination of animals and protective vaccination proved most effective. On the other hand, the least economic losses are observed in conditions of continuous maintenance of appropriate immunity status of animals. Improvement of biosecurity measures proved highly important for substantial reduction of both disease transmission and economic damage in case of epidemic outbreak. Combined with other biosecurity measures such as good on-farm production practices, controlled access of visitors and vehicles, elimination of unnecessary contacts with other pig owners and preventing contacts with wild boars contributes to substantial reduction of the risk for CSF outbreaks. 


\section{CONCLUSIONS}

Based on the results obtained in this research, we may conclude as following:

1. In endemic areas with predominate extensive pig production, relying on CSF control, strategy based on preventive vaccination proved most cost effective.

2. Preventive slaughtering of pigs should be carried out in the radius of max $50 \mathrm{~m}$ around the infected rural holdings, whereas destruction radius for commercial farms is set to $100 \mathrm{~m}$.

3. If selecting the no-vaccination CSF control policy, modified EU strategy based on protective vaccination and limited pig depopulation in a radius of $500 \mathrm{~m}$ around infected commercial farms, i.e., $50 \mathrm{~m}$ around infected family farms type $A$ and $B$ and rural holdings, has proved most cost effective.

4. For all simulation models, where protective vaccination was used as control measures in combination with limited depopulation, there were no statistically significant differences between the effects of protective vaccination if applied within the radius of $10 \mathrm{~km}$ around infected farm as compared to the radius of $3 \mathrm{~km}$.

5. Restriction of natural mating and its limitation to one's own herd significantly reduces the risk of virus transmission and CSF outbreak.

6. Under the present conditions in the Republic of Serbia, it is not reasonable to implement a SCF control strategy without vaccination, particularly on rural holdings and family farms with lower levels of implementation of biosecurity measures.

\section{REFERENCES}

1. Backera J.A, Brouwer H., Schaik G., Roermund H.J.W.: Using mortality data for early detection of Classical Swine Fever in The Netherlands. Preventive Veterinary Medicine, 99, 38-47, 2011.

2. Martınez-Lopez B., Ivorra B., Manuel Ramos A., Fernandez-Carrion E., Alexandrov T., Sanchez-Vizcaino M. J.: Evaluation of the risk of classical swine fever (CSF) spread from backyard pigs to other domestic pigs by using the spatial stochastic disease spread model Be-FAST: The example of Bulgaria. Veterinary Microbiology, 165, 79-85, 2005.

3. Engel B., Bouma A., Stegeman A., Buist W., Elbers A., Kogut J., Dopfer D., Mart de Jong C.M.: When can a veterinarian be expected to detect classical swine fever virus among breeding sows in a herd during an outbreak? Preventive Veterinary Medicine 67, 195-212, 2005. 
4. Gatrell A.C.: Geographical information science and spatial analysis in human health: parallels and issues for animal health research. In: Durr PA and Gatrel AC (ed.): GIS and Spatial Analysis in Veterinary Science. CABI Publishing, Oxfordshire. 69-96, 2004.

5. Harvey N., Reeves A., Schoenbaum M.A., Zagmutt-Vergara F.J., Dube C., Hill A.E., Corso B.A., McNab W.B., Cartwright C.I., Salman M.D.: The North American Animal Disease Spread Model: A simulation model to assist decision making in evaluating animal disease incursions. Preventive Veterinary Medicine 82, 176-197, 2007.

6. Harvey, N., Reeves, A., : Model Description: North American Animal Disease Spread Model 3.2, 2010.

7. Jalvingh A.W., Nielen M., Maurice H., Stegeman A.J., Elbers A.R.W., Dijkhuizen A.A.: Spatial and stochastic simulation to evaluate the impact of events and control measures on the 1997-1998 classical swine fever epidemic in The Netherlands. Preventive Veterinary Medicine 42, 271-295, 1999.

8. Karsten S., Raveb G., Krieter J.: Monte Carlo simulation of classical swine fever epidemics and control I. General concepts and description of the model. Veterinary Microbiology 108, 187-198, 2005a.

9. Karsten S., Raveb G., Krieter J.: Monte Carlo simulation of classical swine fever epidemics and control II. Validation of the model. Veterinary Microbiology 108, 199-205, 2005b.

10. Klinkenberg D., Nielen M., Mourits M.C.M., Jong M.C.M.: The effectiveness of classical swine fever surveillance programs in The Netherlands. Preventive Veterinary Medicine 67, 19-37, 2005.

11. Laddomada A.: Incidence and control of CSF in wild boar in Europe. Veterinary Microbiology 73, 121-130, 2000.

12. Mangena M.J.J., Nielena M., Burrell A.M.: Simulated effect of pig-population density on epidemic size and choice of control strategy for classical swine fever epidemics in The Netherlands. Preventive Veterinary Medicine 56, 141-163, 2002.

13. Martinez-Lopez B., Ivorra B., Ramos A.M., Sanchez-Vizcaino J.M.: A novel spatial and stochastic model to evaluate the within- and betweenfarm transmission of classical swine fever virus. I. General concepts and description of the model. Veterinary Microbiology 147, 300-309, 2011.

14. Plavsic B., Micovic Z., Celebicanin S., Ostojic S., Hristov S., Tesic M., Stanojevic S., Rutilli D., Ivanov J.: Strategy for the control and eradication of classical swine fever in Serbia, International Conference: Preventing the spread of classical swine fever in the border region of Croatia-Serbia. 1731, 2012. 
15. Qui H., Rongxian S., Guangzhi T.: The lapinized Chinese strain vaccine against classical swine fever virus: A retrospective review spanning half a century. Agricultural Sciences in China 5, 1-14, 2006

16. Reeves A., RicHupalo, Kelly A. Patyk, Ashley E. Hill: User's Guide for the North American Animal Disease Spread Model 4.0, $4^{\text {th }}$ Edition, Colorado State University, 2012.

17. Stanojevic S.: Simulation of Classical Swine Fever in the Municipality of Sremska Mitrovica and Sid. Master's Thesis, Faculty of Veterinary Medicine, Belgrade University, 2014.

Primljeno: 30.09.2016.

Odobreno: 10.10.2016. 